\title{
Hinterland Medan City Between Binjai City: A Gravitation Approach
}

\section{Muhammad Nasir}

Faculty of Economic, State University of Medan

nasir@unimed.ac.id

\begin{tabular}{|c|c|}
\hline Article Info & Abstract \\
\hline $\begin{array}{l}\text { Clause history: } \\
\text { Received Juny } 28,2019 \\
\text { Revised July 15,2019 } \\
\text { Accepted July 27,2019 } \\
\text { Available online September } \\
07,2019\end{array}$ & $\begin{array}{l}\text { Regional economy explains that there is an urban } \\
\text { hierarchical relationship, cities that have higher } \\
\text { hierarchy will serve cities that are below it as well as } \\
\text { cities that are in the hierarchy undersupplying cities } \\
\text { that are in the hierarchy above them, so there is a } \\
\text { gravitational relationship between the two. This study }\end{array}$ \\
\hline $\begin{array}{l}\text { Keywords: Gravity model, } \\
\text { economy of medan city, } \\
\text { economy of Binjai city } \\
\text { JEL Classification : P2; } \\
\text { P48; R11 }\end{array}$ & $\begin{array}{l}\text { Medan city to the hinterland of the city of Binjai. } \\
\text { Furthermore, this study also wants to explain its } \\
\text { influence on economic growth in both cities. This } \\
\text { analysis tools used are descriptive statistics, gravity } \\
\text { models, unit root test, co-integration test, optimal lag, } \\
\text { VECM, Granger causality test, impulse response } \\
\text { function, and variance decomposition. The results } \\
\text { showed that the city of Medan has a gravity style } \\
\text { greater than the gravitational style of the city of Binjai. } \\
\text { The VECM estimation results show that the } \\
\text { gravitational variable in the city of Binjai in lag }-1 \text { and } \\
\text { lag- } 2 \text { has a positive and significant effect on the } \\
\text { economy of Medan city. Then the economic variable } \\
\text { of the city of Binjai itself in lag-1, the population of the } \\
\text { city of Medan in lag- } 2 \text { and the gravity of the city of } \\
\text { Medan in lag- } 2 \text { had a positive and significant effect on } \\
\text { the economy of Binjai city. While the variable } \\
\text { population of Binjai city in lag }-1 \text { and residents of the } \\
\text { city of Medan in lag }-1 \text { negatively affected the economy } \\
\text { of Binjai city. }\end{array}$ \\
\hline
\end{tabular}

\section{INTRODUCUTION}

One discussion in regional economics is analyzing the relationship of several regions, including the relationship of two or several adjacent regions. These regions can interact like having the power of attracting each other. This attraction is like the gravitational force of Newton, the implication of which is seen in population migration. Residents migrate due to the attraction of a place. The tensile force arises due to several reasons including the area of a place, an area that has a large enough area to have an attraction for people to migrate to that area. In addition to the area, another factor is a large number of available jobs.

The availability of employment in an area encourages residents of other regions to migrate to the region. Another factor that can encourage interaction is per capita income, the high per capita income of an area indicative of the prosperity of the community in the region means that business opportunities in

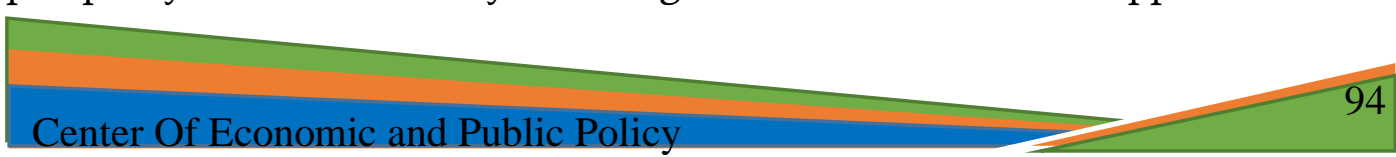


the region are promising. In addition, the availability of public facilities such as road facilities are quite good, educational facilities, health, sports, government centers, transportation and communication, shopping centers and also the distance factor. All of this has an important meaning for the formation of attraction possessed by a region.

Tarigan (2016) explains the relationship between the area of the city and the hinterland area of the city can be divided into three. The first is Generative city, which is a city that has a variety of functions, functions for the city itself as well as for the region behind it to mutually beneficial. This kind of city requires raw materials, consumption materials, labor from the area behind it. In addition, the city area provides the needs of goods and services for the region and transmits innovation and modernization to the region behind it. This interaction creates a mutualistic symbiosis. Second is Parasitive city where a city that lacks its function to foster the area behind it. This kind of city has an undeveloped industry, and even industrial activities are almost the same as the industries in the back region, for example, the tofu manufacturing industry, making tempeh, woven bamboo crafts, rattan, etc. Economic activities in the back region became depressed and less competitive. When the city cannot go out to expand the sales of products produced to other regions outside of its influence, the city is difficult to develop. The last is enclave city (closed city) which means a developing city but the input from the city does not originate from the surrounding area but originates from outside the area. This condition makes the rear area lagging behind. Such cities often occur in large mining areas where the life of the people in the city with the back region has a very severe gap. So that the city's hinterland region did not develop even become tense.

Indicators owned by the city of Medan and the City of Binjai as hinterland areas that can cause attraction can be shown as follows:

Table 1. Distribution of Indicator for the Cities of Medan and the City of Binjai Which Can Lead To an Attraction In 2017

\begin{tabular}{ccc}
\hline Indicator & Medan City & Binjai City \\
\hline Area & $265.10 \mathrm{Km}^{2}$ & $90.23 \mathrm{Km}^{2}$ \\
Population & $2226408 \mathrm{jiwa}$ & $267401 \mathrm{Jiwa}$ \\
Population density & 8409 Jiwa / Km² & 2969 Jiwa / $\mathrm{Km}^{2}$ \\
Labor Force & $875794 \mathrm{Jiwa}$ & $112661 \mathrm{Jiwa}$. \\
Job seeker & $2997 \mathrm{Jiwa}$ & $869 \mathrm{Jiwa}$ \\
Growth Economic & $6.27 \%$ & $5.54 \%$ \\
Income per capita & $59.24 \mathrm{Juta}$ & $25.89 \mathrm{Juta}$ \\
Distance from Medan City to Binjai City & $22 \mathrm{Km}$ & $22 \mathrm{~m}$ \\
\hline
\end{tabular}

Source: BPS, 2017

Table 1 shows that the city of Medan is wider than Binjai City, which is approximately three times that of Binjai. Likewise, when viewed from the population, the ratio of the population of Medan City to Binjai City is eight 
times greater than the population of Binjai City. Furthermore, in terms of population density, the population of Medan City is denser three times the density of the population of Binjai City.

Likewise, the number of the workforce, Medan City has a greater number of the labor force, namely 7.7 times than Binjai City. Furthermore, the number of job seekers recorded in Medan City is quite large compared to Binjai city, which is three times that of Binjai City. Apart from that if viewed from an economic standpoint, the economic growth of Medan City is greater than Binjai City which is $6.27 \%$ compared to $5.54 \%$. Likewise, per capita income, the population of Medan city has a per capita income greater than the per capita income of the people of Binjai city which is 2.25 greater than the per capita income of the city of Binjai. The distance between the city of Medan and the city of Binjai is as far as $22 \mathrm{KM}$.

Based on the phenomena that have been stated above, it can be seen that the city of Medan has a large attraction from the city of Binjai. How much attraction can be known through the approach of the gravity model. In addition, the gravity attraction model contributes to the regional economy, for this reason, further analysis is needed. Alfonso (1999) explains that a collection of industries tends to be located in locations that are concentrated in the city area, there are economic agglomerations supported by the hinterland region of the city. According to Alonso (1987) in Fitzsimons and Hogan (1999) found a strong relationship using the gravity model by replacing the mass with population and the strength of gravity with several measures of interaction between two locations.

\section{METHOD}

This study looked at the interaction between the city of Medan and the hinterland of Binjai through a gravity model approach. It is an explanatory research that explains the relationship between exogenous variables and endogenous variables. The sourced of data comes from the city BPS of Medan and the City of Binjai period 1990-2017.

There are several analytical tools used in this study, namely: Descriptive statistics, Gravity Model, and Vector Error Correction Model (VECM).

Agus (2008) said the VECM model used in time series data is not stationary at the level but it is stationary at the difference and cointegrated so that it shows a theoretical relationship between variables. The process of completing the VECM model is as follows:

a.Unit Root Test;

b.Cointegration Test;

c.Determination of Optimal Lag

d.Test the reciprocal relationship of the model:

$\mathrm{YM}=\alpha 0+\sum \alpha 1 \mathrm{DGRM}+\varepsilon 1$

$\mathrm{YB}=\beta 0+\sum \beta 1 \mathrm{DGRB}+\varepsilon 2$

YM and YB in the model means economics of Medan dan Binjai city then DGRM and DGRB are gravity of Medan and Binjai city.

e. Uji kausalitas granger.

f. Analysis Impuls Respons Function.

g. Variance decomposition.

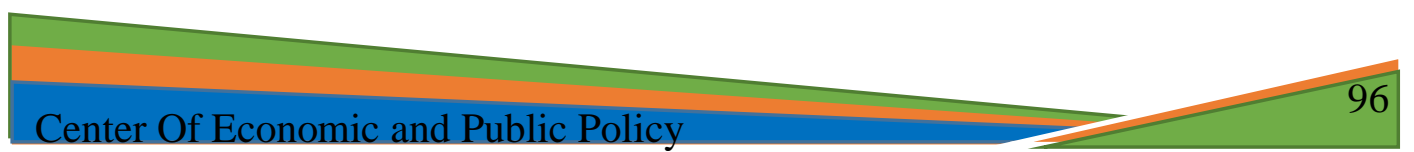




\section{RESULT AND DISCUSSION}

Gravity between the City of Medan against the Hinterland of the City of Binjai

The attraction between two adjacent cities can be known by using the gravity model approach. The gravity model can explain the attractiveness of a region, the greater the value of gravity possessed by a region, the greater the attraction of the region. Determination of city area values has an attraction that can be done using the gravity formula. The following table 2 shows the value of gravity owned by Medan and Binjai cities for the last five years.

Table 2 below explains the results of the calculation stating that the city of Medan has a greater attraction when compared to the city of Binjai, this is indicated by the value of gravity that the city of Medan has is greater for the last five years and the city of Binjai has a smaller gravity value compared to Medan.

Table 2. Gravity Value of Medan City - Binjai City 2013-2017

\begin{tabular}{llcc}
\hline No & Year & $\begin{array}{c}\text { Gravity Value of } \\
\text { Medan City }\end{array}$ & $\begin{array}{c}\text { Gravity Value of } \\
\text { Binjai City }\end{array}$ \\
\hline 1 & 2013 & 2226081292 & 1669560969 \\
\hline 2 & 2014 & 2367608259 & 1775706194 \\
\hline 3 & 2015 & 2417865433 & 1813399074 \\
\hline 4 & 2016 & 2468019143 & 1851014357 \\
\hline 5 & 2017 & 2542610009 & 1906957559 \\
\hline
\end{tabular}

Estimation Analysis of Interaction of Medan City against Hinterland in Binjai City

According the estimated interaction (gravity) reciprocity between the city of Medan - the city of Binjai can be seen in table 3 below:

\section{Table 3. Results of Interaction (Gravity) Between Medan City and Binjai} City

$$
\text { Variabel Endogen }
$$

\begin{tabular}{lllclll}
\multicolumn{1}{c}{$\begin{array}{c}\text { Variabel } \\
\text { Eksogen }\end{array}$} & Koefisien & $\mathrm{t}_{\text {.hitung }}$ & $\begin{array}{c}\text { Sig } \\
\mathrm{pd} \alpha\end{array}$ & Koef & $\mathrm{t}_{\text {.hitung }}$ & $\begin{array}{c}\text { Sig } \\
\mathrm{pd} \alpha\end{array}$ \\
\hline DYB (-1) & 1.028 & 16.9 & 0.05 & & & \\
\hline DPNDDB (-1) & -56.57 & -2.48 & 0.05 & & & \\
\hline DPNDDM (-1) & -9.39 & -3.02 & 0.05 & & & \\
\hline DPNDDM (-2) & 7.026 & 2.26 & 0.05 & & & \\
\hline DGRM (-2) & 1.0005 & 41.8 & 0.05 & & & 0.05 \\
\hline DGRB (-1) & & & & 0.58 & 2.01 & 0.05 \\
\hline DGRB (-2) & & & & 1.87 & 3.16 & 0.05 \\
\hline R.Square & 0.997 & & & 0.97 & & \\
\hline
\end{tabular}




\begin{tabular}{lll}
\hline Adj.R.Square & 0.998 & 0.91 \\
\hline F.Statistik & 787.16 & 14.9 \\
\hline Sort &
\end{tabular}

Source: Data processed

Based on table 3 above, it can be explained that the endogenous variable of the city of Binjai (DYB) can be explained 99\% by the DYB exogenous variable itself at period -1 , Binjai City Population variable (DPNDDB) at period -1 , and Medan City Population variable (DPNDDM) at periods -1 and -2 as well as the Medan City Gravity variable (DGRM) at the -2 period while $1 \%$ is explained by other variables outside of this research, this is explained by the results of the calculation of the R2 value which is equal to 0.999445 or $99 \%$.

From the economic partial side of Binjai city (DYB) in the previous one year period it has a positive effect on the economy of Binjai city this year, if the economic change in Binjai city one year ago amounting to one rupiah will cause economic changes in Binjai city this year by an average of $\mathrm{Rp} 1,02$ significant with a confidence level of $90 \%$. The economy of an area if there is no extreme situation usually increases every year, on the average the last 5 years of the economy of the city of Binjai increased by $5,78 \%$. This means that the economic growth of the city of Binjai grew influenced by one variable, namely the economic period of the previous year.

The population variable of Binjai City in the previous year (DPNDDB 1) has a negative effect on the economy of Binjai City this year, if there is an increase in the population of Binjai City one year ago by one soul, it will cause an economic change in the city of Binjai this year average decreases by Rp 56,57 with a confidence level of $95 \%$. Increasing the number of residents requires a necessity of life, according to Malthus, the need for human life increases more than the increase in the means of satisfaction, this means that an increase in population will reduce the economy of a region with a note that productivity of the population is low.

The variable population of the city of Medan at the previous one year period (DPNDDM -1) has a negative effect on the economy of Binjai city this year, if there is an increase in population of Medan in the past year by one soul, this will cause an economic change in Binjai city this year on average decreased by $\mathrm{Rp} 9,39$ with a confidence level of $95 \%$. According to Meyrdal, the adjacent area can influence each other, this influence can suck the economy of the neighboring region can also improve the economy of its neighbors through back-wash effects and spread of effects. The city of Medan has a larger area compared to the area of Binjai city and the economy of Medan city is higher than the economy of the city of Binjai and the population of the city of Medan is greater when compared to the city of Binjai so that the population of the city of Binjai can increase the economy. But in the previous two years period (DPNDDM-2) has a positive effect on the economy of the city of Binjai, this year if there is an increase in the population of the city of Medan two years ago by one soul, this will cause economic changes in the city of Binjai this year to increase by $\mathrm{Rp}$ 7, 02 with a 95\% confidence level. According to Meyrdal's opinion that was stated earlier that the economy of neighboring regions could increase and suck up the neighboring economy, in this case an increase in the

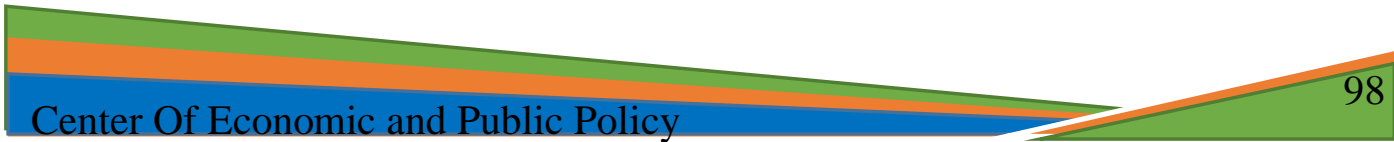


population of the city of Medan two years earlier resulted in an increase in the needs of Medan city residents to fulfill this need products produced by the city of Binjai or in other words the exports of the city of Binjai to the city of Medan increased. This increase in trade volume increases the economy of the city of Binjai.

The interaction (gravity) variable of Medan city-Binjai city two years earlier (DGRM -2) had a positive effect on the economy of Binjai city this year. If the interaction (grafitation) of Medan city two years ago changed by $1 \%$, this would cause the economic change in the city of Binjai this year to increase by an average of $\mathrm{Rp} 1.00$, - with a confidence level of $95 \%$. Increased interaction (grafitasi) city of Medan means that economic activity between the two cities is increasing, the city of Binjai as the hinterland of the city of Medan will fulfill the resources needed by the city of Medan, this fulfillment through trade and economic activities. With this activity the goods and services produced by the city of Binjai are exported to the city of Medan. The goods exported from the city of Binjai to the city of Medan are the result of mining $C$. The city of Binjai is known as the city of rambutan fruit, when the rambutan fruit season increases the frequency of rambutan fruit trade, it is traded to Medan, in addition to meeting the needs of the city of Medan Rambutan is traded to other cities through the city of Medan. The city of Binjai also produces many other fruits besides rambutan fruit including cucumber, yam, watermelon, papaya, banana, sweet potato, corn. In addition, the city of Binjai produces vegetables including vegetables, cassava leaves, spinach, kale, long beans, eggplant, all of which are widely traded to the city of Medan. Apart from that the city of Binjai produces home industry products, the raw materials come from wood and bamboo including wooden spoons, bamboo baskets, bamboo bird nests, bamboo chicken cages. Then the city of Binjai has chicken, its products are traded in the city of Binjai itself also in the city of Medan. Most of the products produced by the city of Binjai are traded to the city of Medan, the results of this trade are one of the sources of income in the city of Binjai which can increase the economy of the city of Binjai.

Furthermore, viewed from the partial economic side of the city of Medan (DYM) in the previous one-year period the interaction variable (grafitasi) of the city of Binjai (DGRB-1) had a positive effect on the economy of Medan this year. If the interaction (graphitation) of the city of Binjai one year ago changed by $1 \%$, it will cause changes in the economy of Medan this year on an average increase of $\mathrm{Rp} 0,57$ with a confidence level of $95 \%$. Increased interaction (gravitation) between the city of Medan and the city of Binjai has caused economic activity between the two cities to change. The city of Medan as a city that is larger compared to the city of Binjai and has greater economic activity certainly needs the city of Binjai as a hinterland to fulfill resource needs. This relationship does not only occur in the previous year but also applies two years before that (DGRB-2) has a positive effect on the economy of Medan this year. If the interaction (gravitation) of the city of Binjai two years ago changed by $1 \%$, it will cause the economic change in Medan this year to increase by an average of $\mathrm{Rp} 1,87$ with a confidence level of $95 \%$. Changing interactions (gravity) between the city of Binjai, Medan, towards an increase has caused the

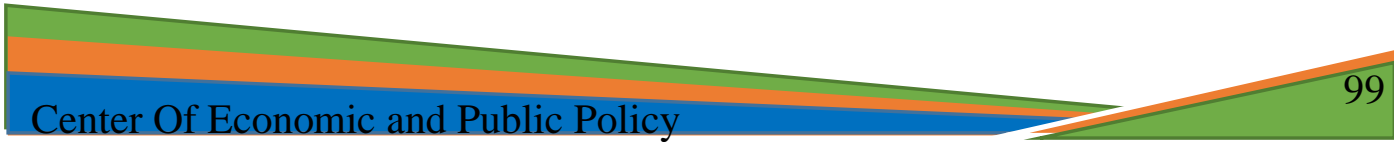


frequency of economic activities of the two cities to increase. Medan City as a metropolitan city has an economic engine, products and services that vary in volume and size. The products and services produced come from sophisticated technology that can meet people's needs. In addition, the city of Medan has a variety of public facilities that can meet the needs of the community including the presence of educational facilities in the form of three state universities, namely the University of North Sumatra, Medan State University, North Sumatra Islamic University.

Likewise, many health facilities are available for hospitals that can provide health services for the community by using high technology, such as Adam Malik general hospital, Pirnadi general hospital and public hospitals that are privately run. In addition, the city of Medan has many trade centers, both modern trade centers and traditional trade centers. Likewise, the city of Medan has financial institutions that can serve the community's needs for financial services. Furthermore, the city of Medan has transportation, communication facilities and also a provincial level government center, namely North Sumatra province. All of this is an attraction for the people of the city of Binjai, residents of the city of Binjai come to the city of Medan to meet their needs. Their arrival in the city of Medan will contribute to the improvement of the economy of the city of Medan.

\section{Granger Causality Analysis}

This analysis is used to look at the causal relationship of the variables under study, from the processing of data that has been done to obtain the results as shown in table 4 below:

Table 4. Granger Causality Test

\begin{tabular}{|c|c|c|c|c|}
\hline Null Hipotesis & $\mathbf{F}_{\text {statistik }}$ & Prob & Result & Relation \\
\hline DTKERB doesn't granger cause DGRB & 4.21296 & 0.0306 & Reject $\mathrm{H}_{0}$ & \multirow{2}{*}{ One way } \\
\hline DGRB doesn't granger cause DTKERB & 0.14814 & 0.8633 & Accept $\mathrm{H}_{0}$ & \\
\hline DTKERM doesn't granger cause DGRB & 2.24736 & 0.1330 & Accept $\mathrm{H}_{0}$ & \multirow{2}{*}{ One way } \\
\hline DGRB doesn't granger cause DTKERM & 4.77367 & 0.0209 & Reject $\mathrm{H}_{0}$ & \\
\hline DTKERB doesn't granger cause DGRM & 4.23777 & 0.0301 & Reject $\mathrm{H}_{0}$ & \multirow{2}{*}{ One way } \\
\hline DGRM doesn't granger cause DTKERB & 0.15026 & 0.8615 & Accept $\mathrm{H}_{0}$ & \\
\hline DTKERM doesn't granger cause DGRM & 2.26085 & 0.1310 & Accept $\mathrm{H}_{0}$ & \multirow{2}{*}{ One way } \\
\hline DGRM doesn't granger cause DTKERM & 4.77370 & 0.0209 & Reject $\mathrm{H}_{0}$ & \\
\hline DTKERB doesn't granger cause DPNDDB & 4.19444 & 0.0310 & Reject $\mathrm{H}_{0}$ & \multirow{2}{*}{ One way } \\
\hline DPNDDB doesn't granger cause DTKERB & 0.12199 & 0.8858 & Accept $\mathrm{H}_{0}$ & \\
\hline DTKERM doesn't granger cause DPNDDB & 0.83831 & 0.4478 & Reject $\mathrm{H}_{0}$ & \multirow{2}{*}{ One way } \\
\hline DPNDDB doesn't granger cause DTKERM & 3.41581 & 0.0540 & Tolak $\mathrm{H}_{0}$ & \\
\hline DTKERM doesn't granger cause DPNDDM & 4.41495 & 0.0266 & Tolak $\mathrm{H}_{0}$ & One way \\
\hline
\end{tabular}




\begin{tabular}{llllll} 
DPNDDM doesn't granger cause DTKERM & 2.55083 & 0.1044 & Accept $\mathrm{H}_{0}$ & \\
DYM doesn't granger cause DTKERM & 0.04482 & 0.9563 & Accept $\mathrm{H}_{0}$ & One way \\
DTKERM doesn't granger cause DYM & 3.25261 & 0.0610 & Reject $\mathrm{H}_{0}$ & \\
\hline
\end{tabular}

Source: Data processed

The figures contained in table 4 above can be explained that in the first model the variable gravity relationship in the city of Binjai (DGRB) is statistically significantly affecting the labor variable that works in the city of Binjai (DTKERB) probability value of 0.0306 so that it rejects the null hypothesis. Furthermore, the labor variable working in the city of Binjai (DTKERB) does not statistically significantly affect the DGRB variable, the probality value is 0.8633 and accepts the null hypothesis. From here it is known that one-way causality of the DGRB variable affects the DTKERB variable and does not apply otherwise.

Furthermore, the second model explains that the gravitational variable of the city of Binjai (DGRB) is not statistically significant in influencing the variable labor force working in the city of Medan (DTKERM), the probability value is 0.1330 and accepts the null hypothesis. Furthermore, the labor variable working in the city of Medan is statistically significantly affecting the gravitational variable of the city of Binjai, the probability value is 0.0209 so that it rejects the null hypothesis. These numbers explain that there is a one-way causality relationship, DTKERM variables affect DGRB variables and do not apply otherwise.

Then the third model explains that the gravitational variable of the city of Medan is statistically significantly influencing the variable of labor employed in Binjai, the probability value is 0.0301 so that it rejects the null hypothesis. Furthermore, the labor variable that works in Binjai statistically does not significantly affect the gravitational variable of Medan city, the probability value is 0.8615 so that it receives $\mathrm{H} 0$. These figures explain that there is oneway causality, the gravitational variable in the city of Medan affects the variables of the workforce working in the city of Binjai and does not apply otherwise.

Furthermore, the fourth model explains that the gravitational variable of the city of Medan is statistically not significantly affecting the workforce variables working in Medan, the probability value is 0.1316 so that it accepts the null hypothesis. Then the labor variable that works in Medan is statistically significant affecting the Medan city gravity variable probability value of 0.0209 so that it rejects the null hypothesis. From this it can be concluded that there is a one-way causality relationship, the variable labor that works in the city of Medan affects the variable gravity of the city of Medan and does not apply otherwise.

Following the fifth model explains that the variable population of the city of Binjai is statistically significantly affecting the labor variable working in Binjai, the probability value of 0.0310 means rejecting the null hypothesis.

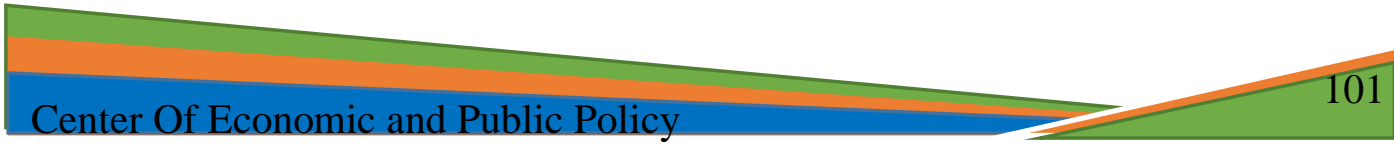


Furthermore, the labor variables working in Binjai are not statistically significant.

Statistically not significantly affect the variable population of the city of Binjai, the probability value is 0.8858 so that it accepts the hypothesis 0 . These numbers explain that there is one-way causality, the variable population of the city of Binjai affects the working variables working in the city of Binjai and does not apply otherwise.

Furthermore, the sixth model explains that the variable population of the city of Binjai is statistically insignificant affecting the variable labor force in the field, its probability value is 0.4478 so that it accepts hypothesis 0 . Then the variable labor force which is employed is statistically significantly affecting the variable population of Binjai city the probability is 0.0540 so that it rejects hypothesis 0 . These numbers explain that there is a one-way causality relationship, the labor variable that works in the field affects the variables of the city population in Binjai and does not apply otherwise.

Next the seventh model explains that the city population variable is statistically significantly affecting the workforce variable in the field, the probability value is 0.0266 so it rejects hypothesis 0 . Then the variable labor that works in the field is statistically insignificant affecting the city population variable, its probability value amounting to 0.1044 so that it accepts hypothesis 0 . These numbers explain that there is a one-way causality relationship, the variable city terrain population influences the variable workforce working in the field and does not apply otherwise.

Furthermore, the eighth model explains that the workforce working in the field is not statistically significant in influencing the economic variables of the city of Medan, the probability value is 0.9563 so it accepts hypothesis 0 . Then the economic variable of Medan city statistically significantly influences the labor force variable in the field, the probability value amounting to 0.0610 so that it rejects hypothesis 0 . These numbers explain that there is a one-way causality relationship, the economic variable of Medan city affects the variables of the workforce working in Medan and does not apply otherwise.

\section{Impulse Response Function Analysis}

The impulse response function is intended to determine the endogenous variable response to the shock of other variables in the model. The responses of these endogenous variables can be explained as follows. that the variable gravity response in the city of Binjai was due to the variable shock of the residents of Binjai city. The shock variable of the city of Binjai causes the variable gravity of the city of Binjai to respond to ups and downs (positive / negative) then the gravity of the city of Binjai is no longer turbulent like the previous period, then reaches balance, it takes 10 years for the Binjai city to reach a balance.

The variable gravity response in the city of Binjai due to the shock of economic variables in the city of Binjai, the shock of economic variables in the city of Binjai caused the variable gravity of Binjai to respond up and down, then the gravitational variable in the city of Binjai no longer fluctuated like the

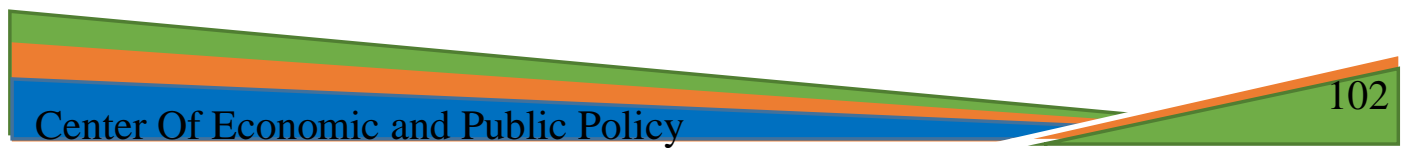


previous period, then reached equilibrium. The gravity variable can reach balance. Then the variable gravity response in the city of Binjai due to the variable shock of gravity in the city of Medan. The presence of the gravitational variable shock in Medan caused the gravitational variable in the city of Binjai to respond up and down, then the gravitational variable in the city of Binjai no longer fluctuated like the previous period, then reached balance, it took 10 years for the Binjai city to reach a balance point.

Furthermore, the variable gravity response in the city of Binjai was due to the shock of the economic variables in the city of Medan. The shock of the economic variables in the city of Medan caused the variable gravity of the city of Binjai to respond up and down, then the gravity variable in the city of Binjai no longer fluctuated like the previous period, then reached equilibrium. It took 10 years for the variable gravity of the city of Binjai to reach equilibrium.

Further, the variable response of the residents of Binjai city is due to the shock of the economic variables in the city of Binjai. The shock of the economic variable in the City of Binjai causes the variable population of the city of Binjai to respond up and down, then the variable population of the City of Binjai no longer flares up like the previous period, then reaches equilibrium. It took 10 years for the variable population of the city of Binjai to reach a balance point.

Then the economic variable response in the city of Binjai was due to the variable shock of gravity in the city of Binjai. The presence of variable gravity of the city of Binjai causes the economic variables of the city of Binjai to respond up and down, then the economic variables of the City of Binjai are no longer volatile like the previous period, then reach balance. It took 10 years for the economic variables of the city of Binjai to reach a balance point.

Furthermore, the economic variable response in the city of Binjai is caused by the variable shock of the residents of Binjai city. the shock variable of the city of Binjai causes the economic variables of the city of Binjai to respond up and down then the economic variables of the city of Binjai no longer fluctuate as in the previous period, then achieve balance. It takes 10 years for the economic variables of Binjai city to reach balance.

Then the economic variable response in the city of Binjai is caused by the shock of the gravity variable in the city of Medan, the presence of Medan's gravity variable causes the economic variables of Binjai city to rise and then the economic variables of Binjai City no longer fluctuate like the previous period, then reach equilibrium. the economy of Binjai city can reach balance.

Further, the economic variable response in the city of Binjai is caused by the shock of the economic variables in the city of Medan, the shock of economic variables in the city of Medan, causing the economic variables of Binjai City to fluctuate then the economic variables of Binjai city no longer fluctuate as before, then reach a balance. the economic variable of the city of Binjai can reach balance.

Then the Medan gravity variable response was caused by the shock of the economic variable in the city of Binjai, the shock of economic variables in the city of Binjai caused the gravitational variable of Medan to respond up and

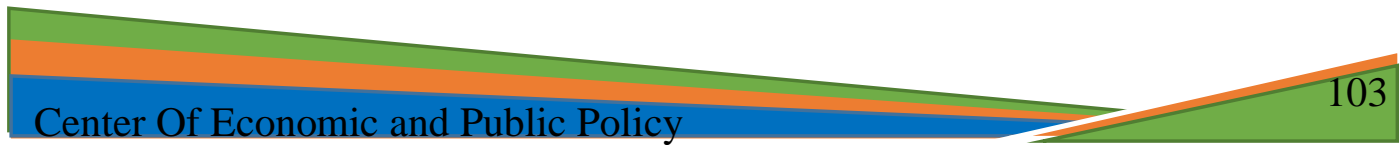


down and the gravitational variable of Medan no longer fluctuated as in the previous period. the city of Medan can reach balance

Furthermore, the gravitational variable response of the city of Medan is due to the shock of the economic variables in the city of Medan. The shock of the economic variables in the city of Medan causes the gravitational variables of Medan to respond up and down then the gravitational variable of Medan city is no longer turbulent like the previous period, then reaches a balance. It takes 10 years for the Medan gravity variable to reach equilibrium.

Then the variable response of the city of Medan residents is due to the shock of the economic variables of the city of Medan, the shock of the economic variables in the city of Medan causes the residents of Medan to respond to the next ups and downs. the variable population of the city of Medan can reach balance.

\section{Analysis of Variance Decomposition}

Variant decomposition can be used to predict the contribution in the form of the percentage of each variable due to the shock of certain variables in the VECM model. Following is the explanation of the decomposition of the economic variable in the city of Binjai (DYB), in the first period the economic variable of the city of Binjai is strongly influenced by the shock of the economy of the city of Binjai itself which is equal to $100 \%$, while the shock from DPNDDB, DGRB, DYM, DPNDDM and DGRM still does not influence. Furthermore, the shock from the economy of the city of Binjai gave a gradual decline in proportion to the economy of Binjai city itself, while the shock from DPNDDB, DGRB, DYM, DPNDDM and DGRM increased. In the 10th period, shock from PNDDB contributed 10.81\%, DGRB contributed $25.08 \%$, DYM contributed $8.64 \%$, DPNDDM contributed $21.22 \%$ and DGRM contributed $16.40 \%$ to the economy of Binjai city. It turns out that the biggest contribution to the economy of the city of Binjai comes from the gravity of the city of Binjai (DGRB).

Variance decomposition of DPNDDB, in the first period the DPNDDB variable was strongly influenced by the shock of DPNDDB itself which was equal to $68.30 \%$ and from DYB by $31.69 \%$ while the shock from DGRB, DYM, DPNDDM and DGRM still had no effect. Furthermore, the shock from DPNDDB gives a proportion gradually decreasing towards DPNDDB itself, as well as the DYB decreases, while the shock from DGRM, DYM, DPNDDM and DGRM increases. In the 10th period, the shock from DYB contributed $29.17 \%$, DGRB was $3.47 \%$, DYM was $4.22 \%$, DPNDDM was $2.33 \%$ and DGRM contributed $0.96 \%$. It turned out that the biggest contribution to the population of the city of Binjai came from DYB (the economy of the city of Binjai).

Variance decomposition of DGRB, at the beginning of the period the DGRB variable was strongly influenced by shock from DPNDDB which was equal to $67.24 \%$, then from DYB at $27.75 \%$, while DGRB itself was $5.00 \%$ while DYM, DPNDDM, DGRM still did not give influence. Furthermore, the shock from DGRB itself gradually increases the proportion, while the shock

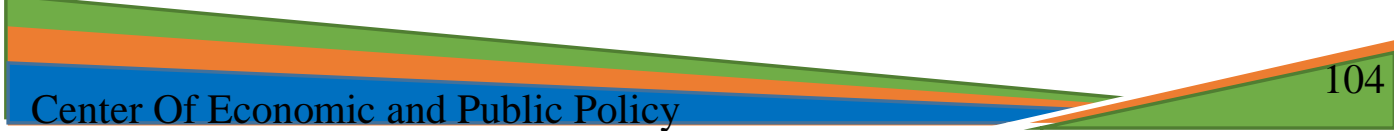


from DYB and DPNDDB decreases towards DGRB, then the shock from DYM, DPNDDM, DGRM increases. In the 10th period, the shock from DYB contributed $25.56 \%$, DPNDDB was $59.59 \%$, DYM was $4.97 \%$, DPNDDM was $1.22 \%$ and DGRM contributed $0.70 \%$ to DGRB. It turned out that the biggest contribution to the gravity of the city of Binjai came from the residents of the city of Binjai.

Variance decoposition of DYM, at the beginning of the period the DYM variable was strongly influenced by the shock of DYM itself which was $93.57 \%$, and from DYB was $5.46 \%$, DPNDDB was $0.01 \%$, DGRB was $0.96 \%$ while the shock was DPNDDM, DGRM still has no influence. Furthermore, the shock from the economy of the city of Medan itself gave a proportion gradually decreasing, while the shock from DYB, DPNDDB, DGRB increased. In the 10th period, the shock from DYB contributed 17.03\%, DPNDDB was $2.01 \%$, DGRB was $11.08 \%$, DPNDDM was $5.26 \%$ and DGRM contributed $7.16 \%$ to DYM. It turns out that the biggest contribution to the economy of Medan comes from the economy of the city of Binjai.

Variance decomposition of DPNDDM, in the initial period the variable DPNDDM was strongly influenced by the shock of DGRB which was equal to $44.12 \%$, then DYB was $11.78 \%$, DPNDDB was $42.39 \%$, DYM was $0.45 \%$, while DPNDDM itself was $1.26 \%$, while DGRM still has no effect. Furthermore, the shock from DPNDDM itself provides slowly increasing proportions, while the shock from DYB, DPNDDB, and DGRB decreases against DPNDDM, while the shock from DYM up and down and DGRM increases. In the 10th period, the shock of DYB contributed $10.53 \%$, DPNDDB was $32.17 \%$, DGRB was $37.48 \%$, DYM was $12.88 \%$, DPNDDM itself was $4.51 \%$ and DGRM contributed $2,42 \%$ of DPNDDM. It turns out that the biggest contribution to the population of the city of Medan comes from the gravity of the city of Binjai.

Variance decomposition of DGRM, in the initial period the DGRM variable was strongly influenced by the shock of DPNDDB which was equal to $67.48 \%$, then DYB was $27.50 \%$, DGRB was $5.01 \%$ and other variables had very little effect on DGRM. In the 10 th period the shock from DYB contributed $25.26 \%$, DPNDDB was $59.85 \%$, DGRB was $7.85 \%$, DYM was $4.99 \%$ and DPNDDM contributed $1.36 \%$ to DGRM. It turns out that the biggest contribution to Gravitation in Medan comes from the residents of Binjai city.

\section{CONCLUSION}

Based on the results of the analysis that has been done, it is concluded that there is a correlation between gravity between the city of Medan and the hinterland of the city of Binjai. The city of Medan has a greater attraction compared to the attraction possessed by the hinterland of Binjai city, this is due to the fact that Medan has an area, population, trade facilities, education, health, transportation, and communication is greater than the facilities owned by the city Binjai. Likewise, Medan City has a greater GRDP when compared to the Binjai City GRDP. Based on the VECM estimation results, it is obtained that the economy of Medan is influenced by the gravity of the city of Binjai in lag- 1 and lag- 2 with a confidence level of $95 \%$. Likewise, the economy of Binjai

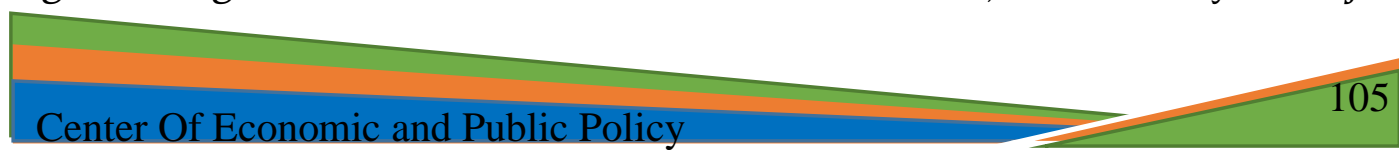


city is influenced by the gravity of the city of Medan in lag 2 with a confidence level of $95 \%$.

From the results of the study it has been stated that there is a gravitational link between the City of Medan and the land of Binjai City and vice versa, and influences the economy of the two cities. To follow up on this finding the authors suggest that the mayors of the two cities conduct a study to further provide recommendations for the program to be implemented by the two cities in relation to the increased economic activity of the two cities. Facilitating the program in the form of distributing information on production, consumption, capital, technology and marketing activities to the products produced by the two cities. Form a small business group on the basis of production and distribution activities to support the economic improvement of the two cities.

\section{REFERENCE}

Alfonso W. 1999. Ketidak Seimbangan Kota dan Daerah. Ekonomi Keuangan Indonesia, Vol XXXVII, No 3.

Bambang Suhardi. 2004. Model Potensial Gravitasi Hansen Untuk Menentukan Pertumbuhan Populasi Daerah, Performa 2004, Vol.3 no.1: 28-32.

Dini Yuniarti. 2007. Analisis Determinan Perdagangan Bilateral Indonesia Pendekatan Gravity Model, Jurnal Ekonomi Pembangunan, Vol.12 No.2: 99-109

Fitzsimon, Emla, Vincent,Hoga, J Peter Neary. 1991. Explaining The Volume of North-South Trade in Ireland: A Gravity Model. The Economic and Social Review, Vol 30, No 4.

Kalbasi Hasan. 2001. The Gravity Model and Global Trade Flows. www.ecomod.net/Conference/ecomod 2001/Paper-w/Kalbasi.pdf.

Nasir, M. 2017. Analisis Pengaruh Sektor Ekonomi Memiliki Nilai LQ>1 Terhadap Peningkatan Kesejahteraan Masyarakat Kota di Sumatra Utara. Jurnal Ekonomi Kawan UMSU.

Ridwan, Ridwan. 2009. Dampak Integrasi Ekonomi Terhadap Investasi di Kawasan ASEAN: Analisis Model Gravitasi. Jurnal Organisasi dan Manajemen, Vol.5, No.2.

Shantika, Martha, Evi, Jurianti. 2016. Analisis Pertumbuhan Ekonomi Kota Pontianak dengan Metode Location Quotient, Shief Share dan Gravitasi. Bimaster, Vol. 5 No.01.

Syafrizal. 2012. Ekonomi Wilayah dan Perkotaan. Jakarta: Raja Grafindo Persada.

Tarigan, Robinson. 2016. Perencanaan Pembangunan Wilayah. Jakarta: Bumi Aksara.

Wiyadi dan Trisnawati, Rina. 2002. Analisis Potensi Daerah Untuk Mengembangkan Wilayah Di Eks-Keresiden Surakarta Menggunakan

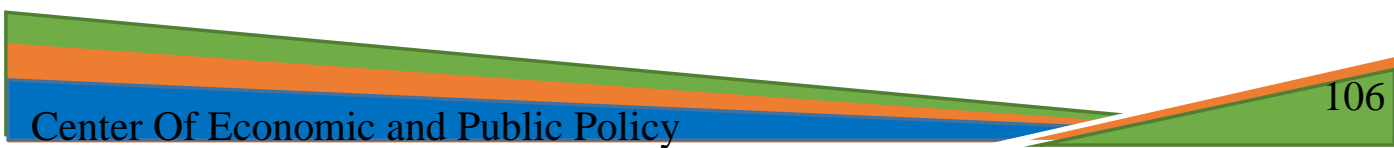


Teori Pusat Pertumbuhan. Jurnal Riset Akuntansi dan Keuangan Indonesia. 